Indian J Anim Health (2021), 60(2): 300-302

DOI: https://doi.org/10.36062/ijah.2021.06921

\title{
Second degree thermal burn in a Lakhimi calf and its successful management: A case report
}

\author{
R. Devi ${ }^{*}$, B. K. Sarma ${ }^{1}$, P. Thakuria ${ }^{2}$, N. Ahmed ${ }^{3}$, S. N. Yadav ${ }^{2}$ and A. J. Nath ${ }^{4}$ \\ ${ }^{1}$ Department of Veterinary Surgery and Radiology, Lakhimpur College of Veterinary Science, Assam \\ Agricultural University, Joyhing- 787 051, North Lakhimpur Assam, India; ${ }^{2}$ Department of Veterinary \\ Medicine, Lakhimpur College of Veterinary Science, Assam Agricultural University, Joyhing-787 051, \\ North Lakhimpur Assam, India; ${ }^{3}$ Department of Animal Reproduction, Gynaecology and Obstetrics, \\ Lakhimpur College of Veterinary Science, Assam Agricultural University, Joyhing- 787 051, North \\ Lakhimpur Assam, India; ${ }^{4}$ Department of Veterinary Microbiology, Lakhimpur College of Veterinary \\ Science, Assam Agricultural University, Joyhing- 787 051, North Lakhimpur Assam, India
}

\begin{abstract}
This present communication shares the successful management of a second degree thermal burn in a Lakhimi breed calf. Besides the proper wound care procedures, the calf was also treated for shock, hypovolemia and prevention of secondary bacterial infection. The animal recovered uneventfully following post-operative care with the application of herbal formulation, clean housing and good nutritional supplement.
\end{abstract}

Key words: Aloevera-turmeric paste, Lakhimi calf, Thermal burn

Localized thermal injuries in animals may be caused by exposure to fire and radiant heat, contact with hot items including hot liquids or steam, inhalation of hot air and exposure to cold temperature (Wohlsein et al., 2016). The degree of a burn injury depends on the temperature of the object and its duration of contact with the body (Venugopalan, 2004). The burn injury can be classified into first degree, second degree, third degree burns depending on the extent of destruction to the tissue (Sagar et al., 2010). In first degree burn, only epidermis is affected whereas in second degree burn, the whole thickness of the skin is involved more or less completely but not the subcutaneous fat and muscle as in third degree burn. In second degree burn, healing is rapid and complete by the regeneration of epithelium unless there is involvement of secondary infection (Nandi et al., 2014). Local pain, redness, swelling, peeling of the skin and blistering were noticed in second degree burn. Along with the local symptoms, bacterial infection, fluid loss, breathing problems were also associated with the burn. This paper reports a second degree thermal burn in a bovine calf and its successful therapeutic management.

A 2 months old Calf of Lakhimi breed weighing $35 \mathrm{~kg}$ was presented to the Veterinary Clinical Complex (VCC) of Lakhimpur College of Veterinary Science with a history of burn injury on the right side of the body. According to the owner, the injury was caused by an accidental splatter of boiled animal feed. On examination, the rectal temperature, respiration rate and heart rate were $101.5^{\circ} \mathrm{F}, 38$ breaths per minute and 70 beats per minute respectively, which were within the normal physiological limit. An extensive burnt area was observed on the right side of the abdomen, the outer side of the right hind limb and the tail. The affected portion was swollen and red with peeling of skin covering the full thickness of skin layers.

After proper examination of the animal, the burnt area was thoroughly lavaged with cold water. In order to re-establish the ionic balance,

*Corresponding Author, E mail: ruma_devi@yahoo.co.in 
the calf was injected with inj. Haemaccel (450 mL). Further, to prevent hypovolaemic shock, Ringer's lactate was infused @ 30 mL/ $\mathrm{kg}$ body weight. The animal was also administered with inj. Melonex @ $0.2 \mathrm{mg} / \mathrm{kg}$ b.wt IM for 3 days and ceftriaxone @ $10 \mathrm{mg} / \mathrm{kg}$ b.wt IM for 7 days respectively to reduce pain and to control secondary bacterial infection respectively. The burnt lesions were dressed with povidone iodine $5 \%$ liquid, and the owner was advised to apply homemade preparation aloevera-turmeric paste topically over the affected area for one month. The calf was administered with inj. Tribivet $3 \mathrm{~mL}$ (total dose) IM for five days and inj. pheneramine maleate $2.5 \mathrm{~mL}$ (total dose) IM for five days as a supportive therapy. Topicure spray was also used to prevent fly infestation. The owner was advised to provide clean and soft bedding to the calf and optimum nutritional care.

The burnt skin started peeling off from the $5^{\text {th }}$ day onwards exposing the underlying tissue (Fig. 2). Development of melanin pigment was also noticed on the $30^{\text {th }}$ day (Fig. 3), which showed the tendency to change to dark colour. Partial healing of the burnt area was noted on the $60^{\text {th }}$ day (Fig. 4) following treatment followed by complete recovery with scar tissue which was thin, shining and hairless after a period of 90 days.

Thermal burns are relatively uncommon in veterinary patients. The pathophysiology of thermal burns in large animals is akin to humans. Most severe burns will produce a local and a systemic response, both of which must be appropriately treated to increase the patient's chances of survival (Geiser and Walker, 1984). A multi-dimensional treatment protocol should be followed to treat the bovine calf (Sagar et al., 2010). The burnt area should be thoroughly lavaged with cold water to limit the further extension of tissue destruction (Mahesh et al., 2016). A better result can be achieved

\section{REFERENCES}

Akbik D, Ghadiri M, Chrzanowski W and Rohanizadeh $\mathrm{R}, 2014$. Curcumin as a wound healing agent. Life Sci, 116(1): 1-7, doi: 10.1016/j.lfs.2014.08.016 with correction of body fluid balance by restoration of ionic balance, reduction of hypovolaemia, and prevention of secondary bacterial infections (Sudheerbabu et al., 2018) as applied in the case. The goals of severe burn therapy are to save the animal's life, relieve pain, early wound closure and minimize deformities. In the present case, since the burn injury covered an extensive area, the animal was provided with both crystalloid and colloidal solution to prevent hypovolaemia. Along with the fluid therapy, secondary bacterial control and other supportive therapies were also offered to the animals. The burnt area was dressed with povidone-iodine as it keeps the wound clean and promotes healing, as suggested by Halbach and De Young (1979). For topical application, the aloevera-turmeric paste was used because a compound called curcumin which is present in turmeric, possesses anti-inflammatory and antimicrobial properties; it could be used in wound healing (Akbik et al., 2014). Whereas aloevera could exhibit the actions of both antiinflammatory and wound healing promotion when applied on a second degree burn wound (Somboonwong et al., 2000).

In conclusion, second degree thermal burn in a bovine calf could successfully be treated by following a protocol of Haemaccel, Ringer's lactate, antibiotic therapy, povidone-iodine dressing along with topical application of aloevera-turmeric paste which is readily available and cost-effective.

Conflict of interest: Authors have no conflict of interest in this study.

\section{ACKNOWLEDGEMENTS}

On behalf of all the authors, I would like to extend my thanks to the Associate Dean, Lakhimpur College of Veterinary Science, Assam Agricultural University, Lakhimpur, Assam, for providing all the required facilities for completing the work.

Geiser DR and Walker RD, 1984. Management of thermal injuries in large animals. Vet Clin North Am Large Anim Pract, 6(1): 91-105, doi: 10.1016/ 
Indian Journal of Animal Health, December, 2021

Management of second degree thermal burn
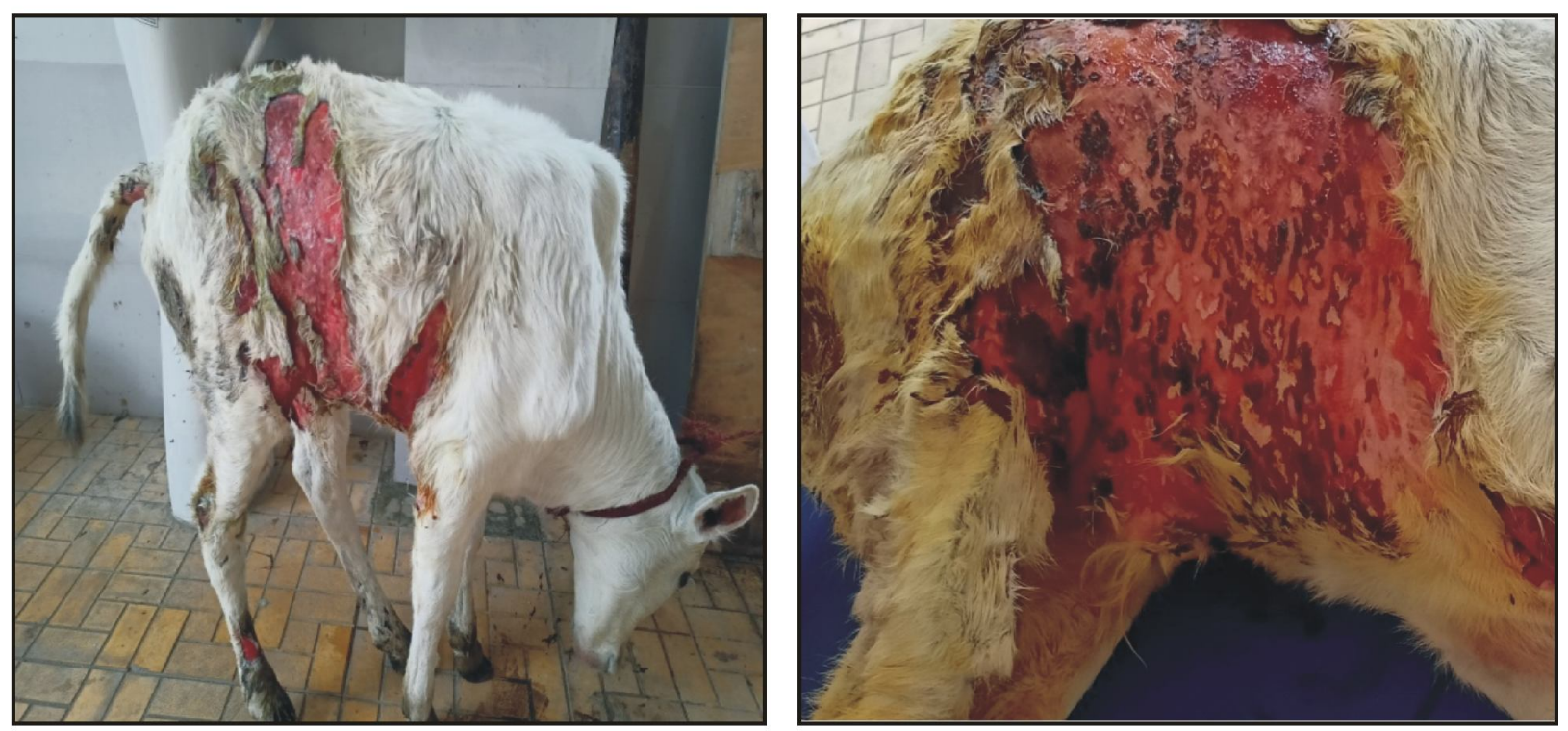

Fig. 1. Photograph showing burn injury on $1^{\text {st }}$ day

Fig. 2. Photograph showing burn injury on $5^{\text {th }}$ day

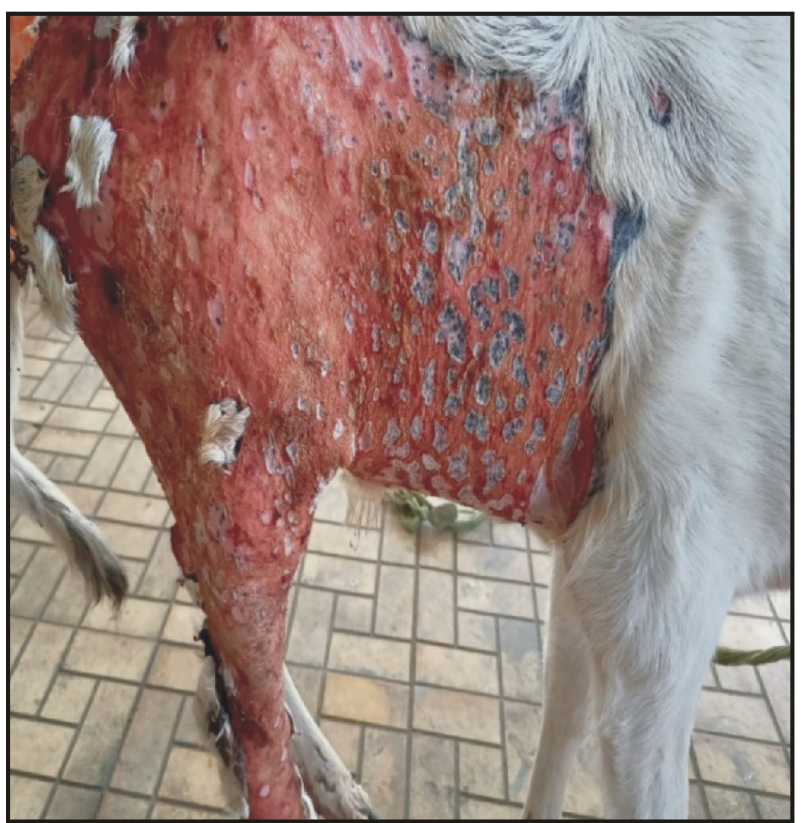

Fig. 3. Photograph showing healing on $30^{\text {th }}$ day

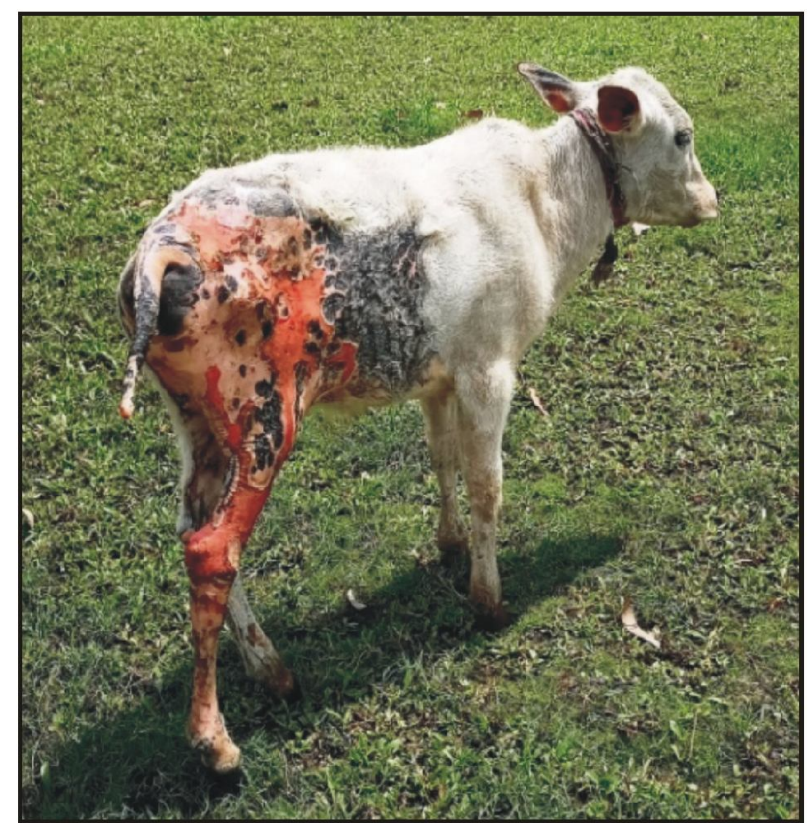

Fig. 4. Photograph showing healing on $60^{\text {th }}$ day 
s0196-9846(17)30251-3

Halbach N and De Young D, 1979. Treatment and management of major burns. Lowa State University Vet, 41(3): 120-126

Nandi SK, Haldar S and Hoque MA, 2014. Text Book on Veterinary Surgery and Radiology. Kalyani Publishers, New Delhi, India, pp 76-78

Mahesh R, Jaya Kiran K, Kamalakar G and Jagadeesh MV, 2016. Successful management of second degree burns in a crossbred cow: A case report. Int J Sci Environ Technol, 5(3): 1008-1010

Sagar PV, Rajesh K, Kavitha KL and Suresh K, 2010. Clinical management of second degree burns in a she buffalo: A Case Report. Buffalo Bull, 29(1): 65-68

Somboonwong J, Thanamittramanee S, Jariyapongskul A and Patumraj S, 2000. Therapeutic effects of Aloe vera on cutaneous microcirculation and wound healing in second degree burn model in rats. $\mathbf{J}$ Med Assoc Thai, 83(4): 417-425

Sudheerbabu G, Divya T and Raja K, 2018. Therapeutic management of second degree burns in buffalo. Int J Sci Environ Technol, 7(2): 482-485

Venugopalan A, 2004. Essentials of Veterinary Surgery. Burns and Scalds. Chapter 8. Oxford and IBH Publishing Co. Pvt. Ltd, New Delhi, pp 70-74

Wohlsein P, Peters M, Schulze C and Baumgartner W, 2016. Thermal injuries in veterinary forensic pathology.Vet Pathol, 53(5): 1001-1017, doi: $10.1177 / 0300985816643368$

Received 22.06.21, Accepted - 11.08.2021, Published - 04.09.2021 (Online), 01.12.2021(Print) Section Editor: Prof. S. K. Nandi, Associate Editor 